\title{
Genotype and Grafting Techniques Effects on Survival and Growth of Camu Camu Plants
}

\author{
Carlos Abanto Rodriguez ${ }^{1}$, Edvan Alves Chagas ${ }^{2}$, Luis Felipe Paes de Almeida ${ }^{3}$, Jhon Paul Mathews Delgado ${ }^{3}$, \\ Dennis del Castillo Torres ${ }^{1}$, Mario Pinedo Panduro ${ }^{1}$, Victor Emilio Correa da Silva ${ }^{1}$ \\ \& José Sanchez Choy Sanchez ${ }^{4}$ \\ ${ }^{1}$ Research Institute of the Peruvian Amazon, IIAP, Peru \\ ${ }^{2}$ Empresa Brasilera de Pesquisa Agropecuaria, Embrapa, Brazil \\ ${ }^{3}$ Instituto Nacional de Pesquisas da Amazônia, INPA, Brazil \\ ${ }^{4}$ Universidad Nacional Intercultural de la Amazonía, UNIA, Peru \\ Correspondence: Carlos Abanto Rodriguez, Research Institute of the Peruvian Amazon, IIAP, Peru. E-mail: \\ carforestal24@gmail.com
}

Received: February 25, 2015 Accepted: March 30, 2015 Online Published: May 15, 2015

doi:10.5539/jas.v7n6p160 URL: http://dx.doi.org/10.5539/jas.v7n6p160

\begin{abstract}
Camu camu is a fruit native to the Amazon, that stands out for high content of vitamin C $(3,133 \mathrm{mg} / 100 \mathrm{~g}$ of pulp). Is in process of domestication and therefore it is investigating a method of vegetative propagation to enable progress in the process of genetic improvement. The objective of this work was to determine the influence of genotype and grafting technique on the success and graft quality in camu camu plants. The trial was conducted using an experimental Randomized Complete Block design (RCB) with factorial scheme 9Ax3B, three blocks and 10 grafted plants per experimental unit. The factor A represented 9 clones of camu camu and factor B, three grafting techniques: Chip budding, b) Splice graft and c) Cleft graft. The experiment was conducted for 110 days to determine the sprouting time (beginning of the expansion of the first pair of leaves), the survival rate, sprout length and number of leaves. Significant interactions between the factors for the variables survival rate, sprout length and number of leaves were observed. The results show that the survival rate was influenced by the intrinsic effects of clone's genotypic variability, presenting a high degree of dispersion, which was between $96.66 \%$ and $26.67 \%$. With respect to grafting technique, the chip budding had higher response of survival rate, sprout length and number of leaves. Based on these results it is possible to conclude that the effect of genotypic variability and grafting method have influenced significantly on quantity and quality of camu camu grafting. The higher values of survival rate and vegetative vigour obtained allow recommending the use of chip budding technique for vegetative propagation of camu camu genotypes evaluated in this study.
\end{abstract}

Keywords: Myrciaria dubia, Vitamin C, domestication, vegetative propagation, IIAP

\section{Introduction}

Twice winner of the Nobel Prize, Linus Pauling, revealed the existence of antioxidants and neutralizing action against destructive free radicals. These radicals are highly aggressive. Causing a body of degenerative diseases such as cancer, diabetes and arteriosclerosis (Pinedo et al., 2010). In this context, camu camu, a native fruit species of the Amazon, comes as a natural source of vitamin C, containing up to $3571 \mathrm{mg} / 100 \mathrm{gm}$ of pulp, possessing antioxidants and minerals, considered a fruit with nutraceutical value. Currently, it represents an Amazonian agrobiodiversity resource with the greatest prospects in domestic and international markets (Almeida et al., 2014; Abanto et al., 2014).

Camu camu is normally propagated by seed leading to large variation in fruit production, low and late fruiting, diminished fruit quality and varying vitamin $C$ content between one plant and another (Salazar et al., 2012). It also represents high genetic variability due to quantitative and qualitative hermaphrodite flower pollination. This creates a $91 \%$ alogamy and $9 \%$ autogamy, producing a wide phenotypic variability, which determines a high heterogeneity in yield $\left(\mathrm{kg} \mathrm{ha}^{-1}\right)$ and ascorbic acid content, which becomes an unsustainable production (Vasquez, 2000). Therefore it becomes necessary to use duly verified camu camu genotypes of high genetic quality (good fruit yield and vitamin C content) (Salazar et al., 2012). Therefore, asexual multiplication of selected clones may 
significantly increase the productivity of this species. This will allow the anticipation of the production period and ensure the maintenance of desirable characteristics of the parent plants to the progenies, ensuring the formation of homogeneous plantations to facilitate their management (Pinedo et al., 2010; Giraldo et al., 2009; Chagas et al., 2012).

The IIAP Pucallpa currently has 09 camu camu genotypes (clones) with high yield potential and good agronomic characteristics, which has been propagated through cuttings with sub-irrigation mini-greenhouse. However, previous works verified that the phenotypic variability influenced significantly the rooting process, affecting the propagation of some camu camu clones. In that sense another method of vegetative propagation is needed to allow the propagation for this genotypes.

The grafting methods with different techniques are presented as a viable alternative for propagation. Grafting is a vegetative technique of propagation which is used in timber and fruit species, primarily species with propagation difficulties. The grafting method consists of two parts placed in contact, joining tissues and subsequently originating in a new plant (Hartmann et al., 2002). This process is basically composed of two parts: a scion and a rootstock. This method increases fruit production, decreases plant habit, reduces the period of flowering and fruiting, and guarantees the maintenance of the characteristics of one elite material (Fachinello et al., 2005). The development of this method was a large breakthrough for the domestication and cultivation of plants (Enciso, 1993).

According to Suguino (2002), the grafting techniques that are most used in camu camu are cleft graft, chip budding and splice graft. The camu camu experts cite that grafting should be performed at $30 \mathrm{~cm}$ from the ground when the rootstock is between 6 and $9 \mathrm{~mm}$ in diameter and about 0.70 to $1.00 \mathrm{~mm}$ in length (Suguino, 2002). In Pucallpa's INIA experimental station, several years of research has resulted in camu camu grafting by the chip budding method. Alternatively, Salazar (2012) working with different grafting techniques and three genotypes of camu camu concluded that the MD-017 and MD-015 genotypes using cleft graft, obtained the best results with sprouting percentages of $90 \%$ and $87.50 \%$, respectively, and concluded that this graft was an innovation to the camu camu propagation. This gives the plant bushy characteristics typical of simultaneous growth of several branches. In this context the present study was to determine the effect of genotype and grafting techniques in the survival rate and initial growth of camu camu plants under nursery conditions.

\section{Methods}

The study was conducted from April to August 2014, in the Research Institute of the Peruvian Amazon nursery, located at km 12.4 of Highway Federico Basadre Yarinacocha district province of Coronel Portillo Region Ucayali, located $8^{\circ} 22^{\prime} 31^{\prime \prime}$ south latitude and $74^{\circ} 34^{\prime} 35^{\prime \prime}$ west longitude and at an altitude of 154 meters (Figure 1).

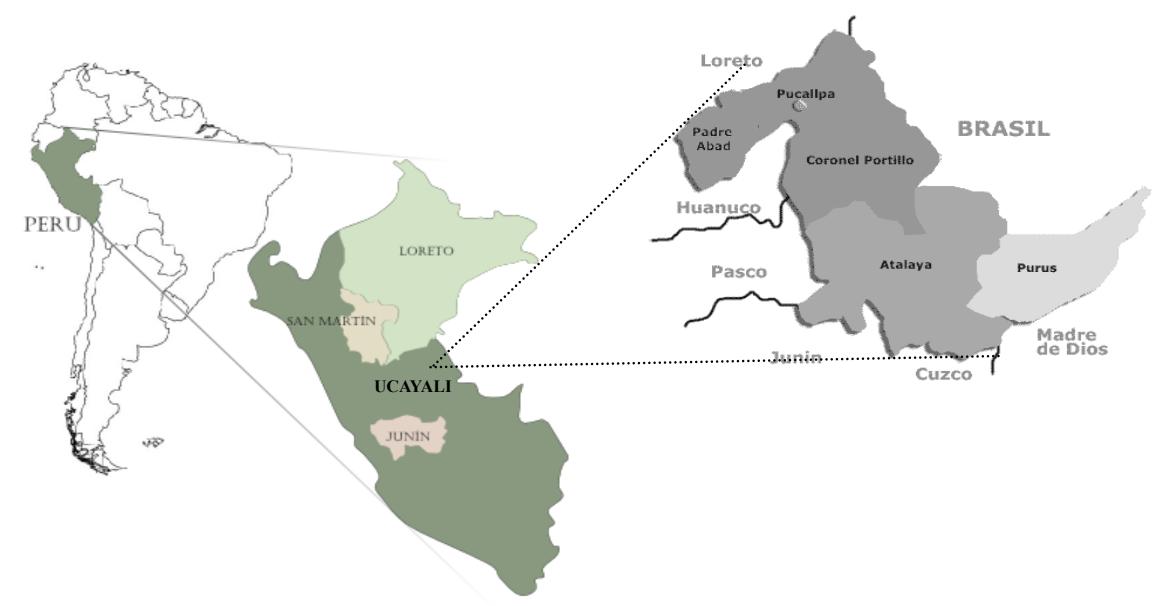

Figure 1. Location of the study 
The climate is tropical, with warm temperatures throughout the year, classified as equatorial climate according to the Köppen system. The average annual temperature is $26{ }^{\circ} \mathrm{C}$, with an average of $25{ }^{\circ} \mathrm{C}$ in July and $26.5{ }^{\circ} \mathrm{C}$ September to January. The average maximum temperature is $33{ }^{\circ} \mathrm{C}$ and the minimum temperature is $21.5^{\circ} \mathrm{C}$. Annual rainfall precipitation is approximately $1,570 \mathrm{~mm}$ with higher precipitation between October and April. In the study period the rainfall precipitation, relative humidity, minimum and maximum temperature were 452.9 $\mathrm{mm}, 85.5 \% ; 22.7^{\circ} \mathrm{C}$ and $31.1^{\circ} \mathrm{C}$ respectively (IIAP, 2014). Plants used as rootstocks were obtained from seeds of mother plants from the Research Institute IIAP Ucayali, and were germinated in September 2013. Seedlings were planted in substrate composed of soil and chicken manure at a 1:1 ratio. After 8 months, when the plants reached an average basal diameter of $0.95 \mathrm{~mm}$ and a height of $1 \mathrm{~m}$, the experiment was conducted with the three grafting technique: Chip budding, cleft and splices grafting. The cuts were made $30 \mathrm{~cm}$ from ground using plastic tape, parafilm, razor blades and pruning shears (Figure 2a). Nine genotypes were used as a graft, from camu camu collection of IIAP- Ucayali, noted for having a high content of vitamin C (1800 mg/100 g pulp) and high fruit yield (20 t/year). They are: ca39, CA242, ca253, CA48, ca294, CA51, CA81, ca306 (Figure 2b).
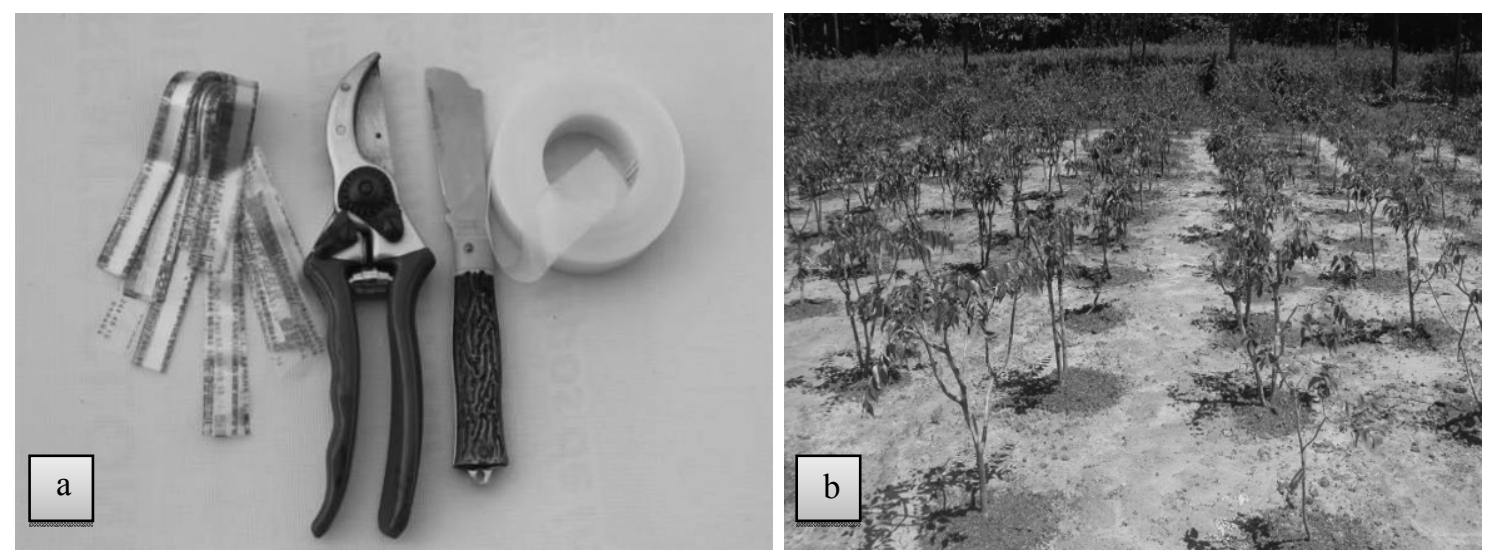

Figure 2. Material used for grafting (a) and clone collection of schruby camu camu IIAP Ucayali/Yarinacocha-Ucayali, Peru

For chip budding technique, a transverse cut was made in the rootstock. Then about $2 \mathrm{~cm}$ above the same direction a second cut down was performed until it connects with the first cut. The cut was made to remove the bud to be used for grafting, and was performed exactly the same as was performed in the rootstock (Rosati \& Arana, 2003). Subsequently, wrapping is performed with polyethylene tape, being removed after 25 to 30 days, as required for the scion/rootstock tissue formation (Figure 3). 


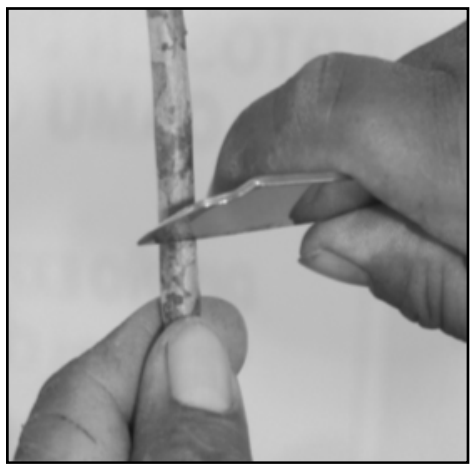

1) Cross section in the rootstock

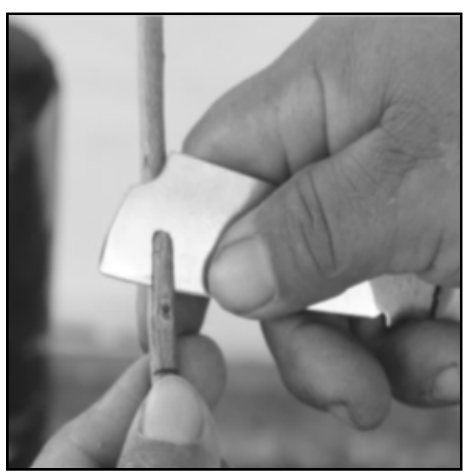

4) Obtaining chip budding with $2 \mathrm{~cm}$ of length with 1 bud

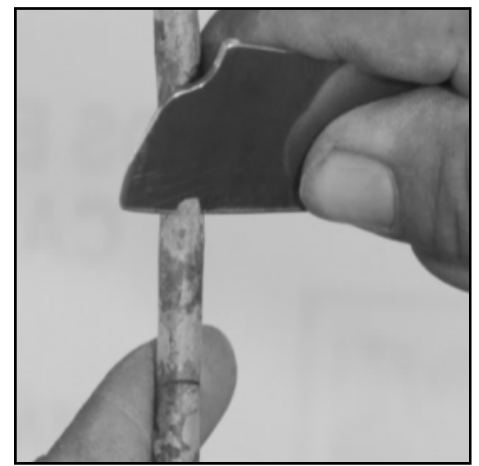

2) $2 \mathrm{~cm}$ cut from up to down

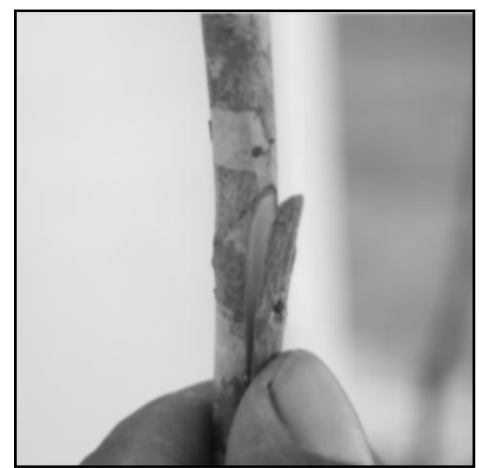

5) Rootstock with chip bud union

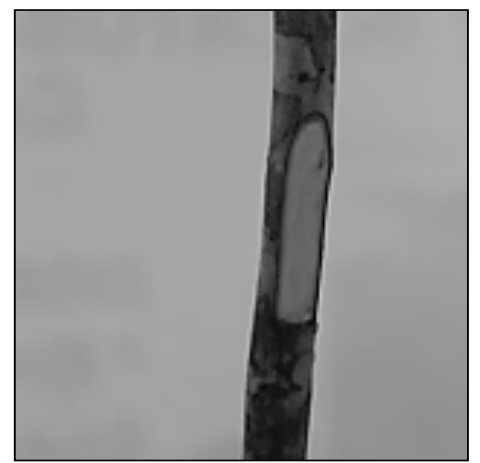

3) Section ready to receive chip budding

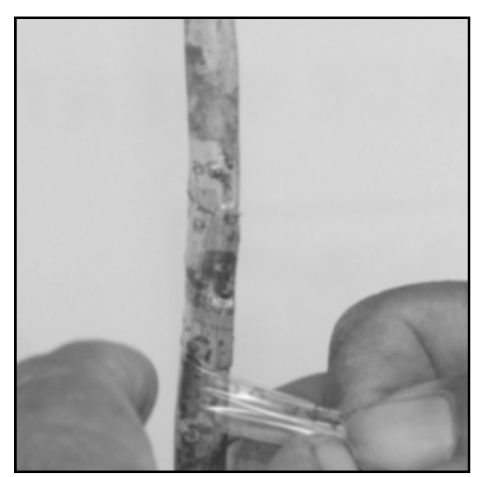

6) Wrapping rootstock and chip bud with plastic tape

Figure 3. Procedure for chip budding technique/Yarinacocha-Ucayali, Peru

For cleft grafting, rootstock and scion should be with the same diameter. In the center of rootstock, a longitudinal cut with approximately $2 \mathrm{~cm}$ was performed. The scions were packed and prepared with a blade. Then its two sides were revel cutted (wedge), trying to preserve the cambium, as it is the key of the graft. Subsequently both sides were firmly joined with polyethylene tape, ensuring cambium layers matching. Finally the scion is protected with Parafilm ${ }^{\circledR}$ tape to create a humid chamber protection and prevent ingress of water (Figure 4). 


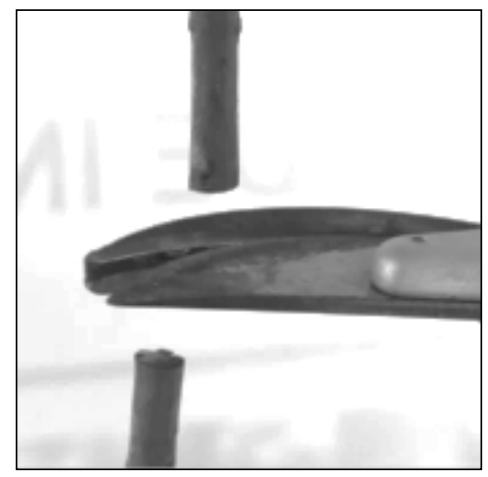

1) Cross section of rootstock

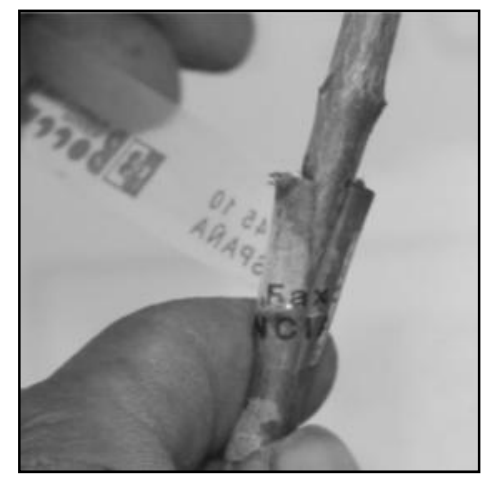

4) Wraping rootstock and scion with polyethylene tape

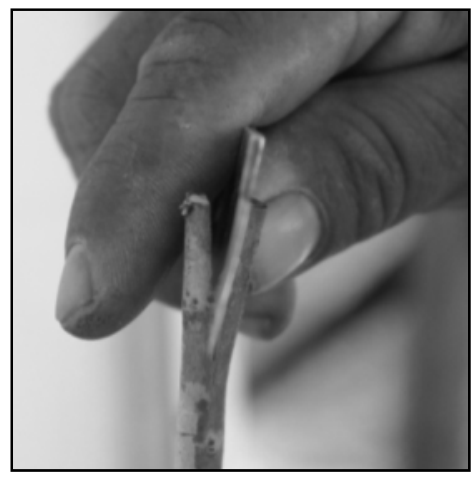

2) Longitudinal cut in the rootstock

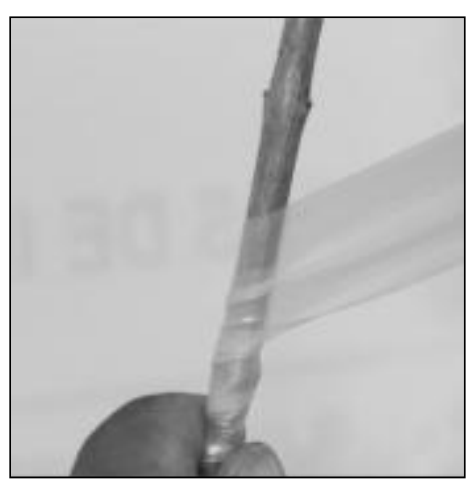

5) Graft protection with

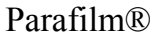

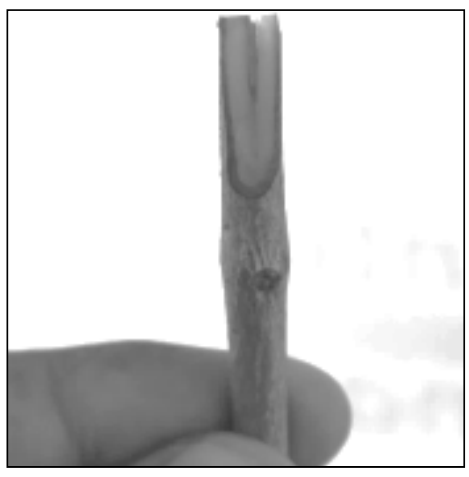

3) Sloping cuts made on exactly opposite sides of the scion (wedge)

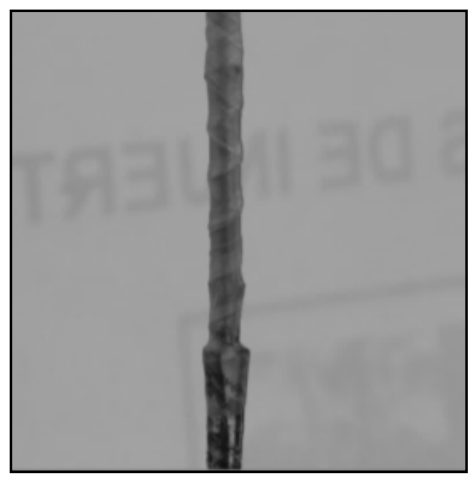

6) Graft ready to be monitored and evaluated

Figure 4. Procedure for the cleft grafting technique/Yarinacocha-Ucayali, Peru

To propagate with splice grafting technique, a bevel cut was made in the rootstock with approximately $2 \mathrm{~cm}$ at a height of $30 \mathrm{~cm}$ from the ground. The same method was done in the scion, and then the rootstock and scion are wrapped with tape so they are securely joined. It is also necessary that the rootstock and the graft be about the same diameter. Finally the graft is protected with Parafilm ${ }^{\circledR}$ tape in order to create a wet chamber and protect against outside humidity (Figure 5). 


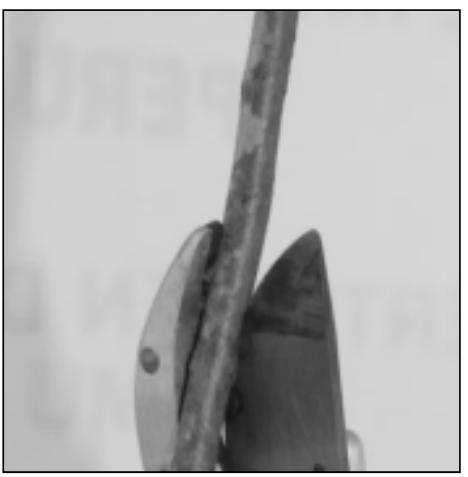

1) Rootstock bevel cut

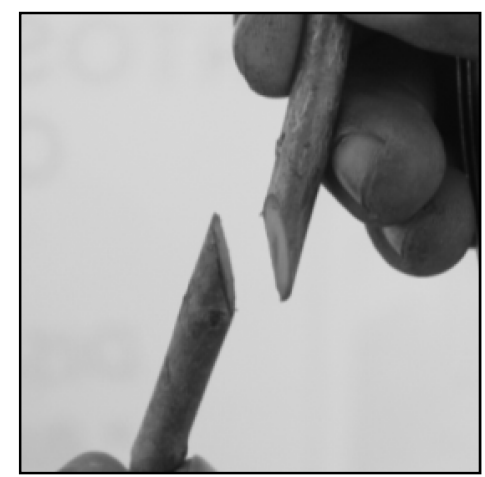

4) Rootstock and scion graft union with the same diameter

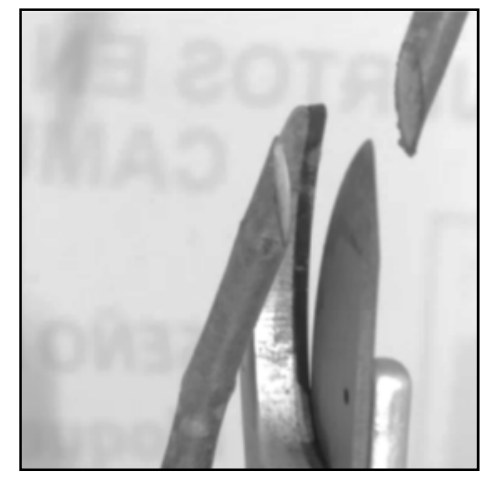

2) Scion bevel cut

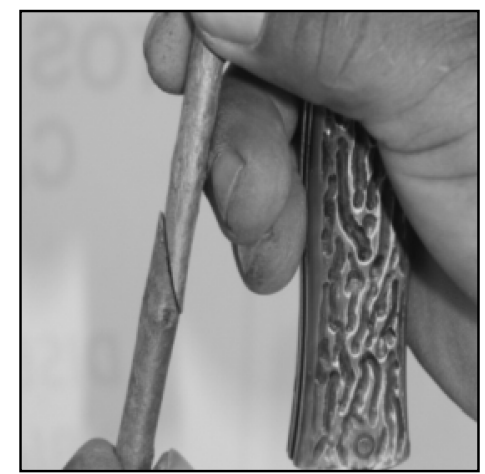

5) Joining tissues of scion and rootstock

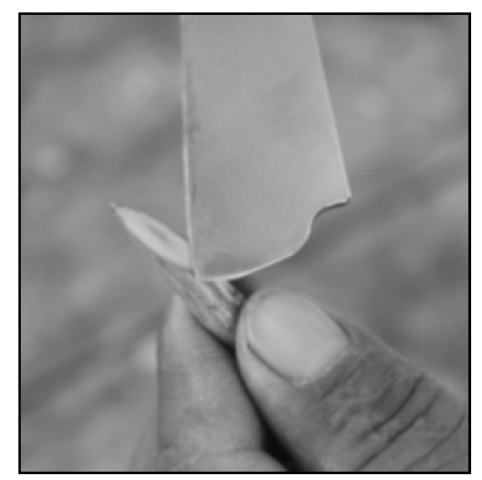

3) Cut adjustment with sharp blade

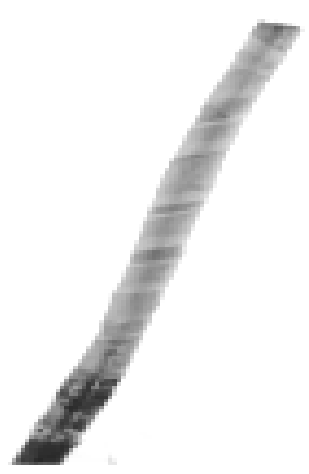

6) Wraping the graft with Parafilm $\AA$

Figure 5. Procedure for the splice grafting technique/Yarinacocha-Ucayali, Peru

The study was conducted using a complete randomized block design with factorial arrangement with three replicates $9 \mathrm{~A} \times 3 \mathrm{~B}$ and 10 grafted plants per experimental unit. Factor A consisted of nine clones of camu camu and factor B by three grafting techniques: Chip budding, b) Splice grafting and c) Cleft grafting. The experiment was evaluated weekly determining the time of sprouting, after of 110 days was obtained the percentage of survival, sprout length $(\mathrm{cm})$ and the number of leaves. Data were transfomed and analyzed using analysis of variance and treatment means were compared statistically by the Tukey test at $5 \%$ probability $(\mathrm{P}<0.05)$ using the statistical analysis program SISVAR (Ferreira, 2010).

\section{Results}

In Figure 6, it is observed that the splice grafting and cleft grafting were the first to sprout in an average time of 16 days. On the other hand, chip budding took 40 days. 


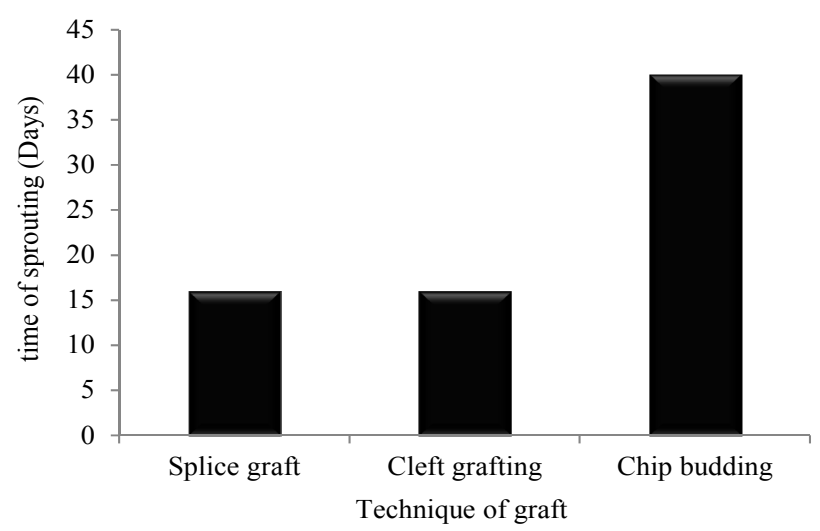

Figure 6. Time of sprouting (days) of different techniques of graft plants camu camu/Yarinacocha-Ucayali, Peru

The summary of the analysis of variance (Table 1) shows interaction between genotype and grafting techniques factors for the variables: survival rate, sprout length and number of leaves. The results show that camu camu presents variability and clones influence on the process of survival rate and initial growth of plants depending on the grafting techniques used.

Table 1. Summary of analysis of variance (ANOVA) the survival rate, sprout length $(\mathrm{cm})$, number of leaves per sprout, by the effect of the clones and grafting techniques, after 110 days of the operation on camu camu plants/Yarinacocha-Ucayali, Peru

\begin{tabular}{lllll}
\hline \multirow{2}{*}{ Variation factor } & DF & \multicolumn{3}{c}{ Mean square } \\
\cline { 3 - 5 } & & Survival rate (\%) & Sprout length $(\mathrm{cm})$ & Number of leaves \\
\hline Genotype (G) & 8 & $973.46^{* *}$ & $127.01^{* *}$ & $115.83^{* *}$ \\
Grafting Techniques (GT) & 2 & $4675.31^{* *}$ & $1333.87^{* *}$ & $766.39^{* *}$ \\
GxGT & 16 & $290.59^{* *}$ & $56.91^{* *}$ & $24.39^{* *}$ \\
Residue & 52 & 167.76 & 8.11 & 3.87 \\
\hline CV $(\%)$ & & 17.43 & 28.81 & 18.70 \\
\hline
\end{tabular}

Note. $*$ Significant at $1 \% ;{ }^{\text {ns }}$ not significant by ANOVA.

Regarding the survival rate, clones ca306 and ca84 obtained the best results with $96.66 \%$ each, when used chip budding. With cleft grafting they obtained 76.66 and $86.67 \%$ respectively. On the other hand, when splice grafting was used it had lower results. The same behavior was obtained when ca39 and ca51 clones were splice grafted, obtained 46.67, 26 and 67\% respectively. However it was observed that, although there were no statistically significant differences in most genotypes, the chip budding had a superior performance (Table 2). 
Table 2. Survival rate (\%), sprout length $(\mathrm{cm})$ and number of leaves by the effect of the genotypes of camu camu and different techniques of grafts/Yarinacocha-Ucayali, Peru

\begin{tabular}{|c|c|c|c|c|c|c|c|c|c|}
\hline \multirow{3}{*}{ Genotype } & \multicolumn{9}{|c|}{ Grafting Techniques } \\
\hline & \multicolumn{3}{|c|}{ Survival rate (\%) } & \multicolumn{3}{|c|}{ Sprout length $(\mathrm{cm})$} & \multicolumn{3}{|c|}{ Number of leaves } \\
\hline & $\begin{array}{l}\text { Chip } \\
\text { budding }\end{array}$ & $\begin{array}{l}\text { Cleft } \\
\text { grafting }\end{array}$ & $\begin{array}{l}\text { Splice } \\
\text { grafting }\end{array}$ & $\begin{array}{l}\text { Chip } \\
\text { budding }\end{array}$ & $\begin{array}{l}\text { Cleft } \\
\text { grafting }\end{array}$ & $\begin{array}{l}\text { Splice } \\
\text { graft }\end{array}$ & $\begin{array}{l}\text { Chip } \\
\text { budding }\end{array}$ & $\begin{array}{l}\text { Cleft } \\
\text { grafting }\end{array}$ & $\begin{array}{l}\text { Splice } \\
\text { grafting }\end{array}$ \\
\hline ca39 & $70.00 \mathrm{Ab}$ & $56.67 \mathrm{Ab}$ & 46.67Bab & $8.53 \mathrm{Ae}$ & $4.97 \mathrm{Ab}$ & $3.14 \mathrm{Aa}$ & $9.33 \mathrm{Ae}$ & $6.90 \mathrm{ABbc}$ & $3.86 \mathrm{Bb}$ \\
\hline ca242 & $80.00 \mathrm{Aa}$ & $60.00 \mathrm{Aab}$ & $70.00 \mathrm{Aa}$ & $18.93 \mathrm{Abc}$ & $5.60 \mathrm{Bb}$ & $3.63 \mathrm{Ba}$ & $17.47 \mathrm{Abc}$ & $8.07 \mathrm{Bbc}$ & 4.80Bab \\
\hline ca253 & $80.00 \mathrm{Aa}$ & 86.67Aab & $63.33 \mathrm{Ba}$ & 10.46Ade & 7.86Aab & $5.97 \mathrm{Aa}$ & 11.60Ade & $9.87 \mathrm{ABbc}$ & $6.93 \mathrm{Bab}$ \\
\hline ca168 & 86.66Aa & 66.67Aab & 66.67Aa & $21.33 \mathrm{Ab}$ & $4.23 \mathrm{Bb}$ & $3.70 \mathrm{Ba}$ & 16.06Abcd & $6.20 \mathrm{Bc}$ & $5.06 \mathrm{Bab}$ \\
\hline ca294 & 93.33 Aa & $93.33 \mathrm{Aa}$ & $73.33 \mathrm{Aa}$ & $35.46 \mathrm{Aa}$ & $13.20 \mathrm{Ba}$ & $6.20 \mathrm{Ca}$ & $30.87 \mathrm{Aa}$ & $17.67 \mathrm{Ba}$ & $9.67 \mathrm{Ca}$ \\
\hline ca51 & $93.33 \mathrm{Aa}$ & $56.67 \mathrm{Bb}$ & $26.67 \mathrm{Cb}$ & $23.53 \mathrm{Ab}$ & 8.20Bab & $3.58 \mathrm{Ba}$ & $19.60 \mathrm{Ab}$ & $9.20 \mathrm{Bbc}$ & $3.78 \mathrm{Cb}$ \\
\hline ca81 & 93.33Aa & $80.00 \mathrm{Aab}$ & $73.33 \mathrm{Ba}$ & 12.67Acde & 6.67Bab & $3.17 \mathrm{Ba}$ & 13.87Acde & $7.93 \mathrm{Bbc}$ & $5.33 \mathrm{Bab}$ \\
\hline ca306 & 96.66Aa & 76.67Aab & $67.67 \mathrm{Ba}$ & 16.70Abcd & $10.87 \mathrm{Bab}$ & $7.06 \mathrm{Ba}$ & $14.80 \mathrm{Abcd}$ & $11.47 \mathrm{ABb}$ & 7.93Bab \\
\hline ca84 & $96.66 \mathrm{Aa}$ & 86.67Aab & $67.67 \mathrm{Ba}$ & 12.60Acde & $5.53 \mathrm{Bb}$ & $3.03 \mathrm{Ba}$ & 13.20Acde & $8.07 \mathrm{Bbc}$ & 4.93Bab \\
\hline Average & 73.7 & 61.48 & 61.48 & 17.8 & 7.45 & 4.38 & 21.48 & 9.48 & 5.81 \\
\hline
\end{tabular}

Note. In each genotype (line), means followed by at least one capital letter do not differ by Tukey test $(\mathrm{p}<0.05)$.

In each grafting technique (column) means with at least one lower case letter do not differ by Tukey test $(\mathrm{p}<$ $0.05)$.

Also shown in Table 2, the survival rate was influenced by the genotypic variability of the clones, which was expressed at a high degree of dispersion ranged between 96.66 and $26.67 \%$. This result is not satisfatory because, on a commercial level, the vegetative propagation below $70 \%$ is not considered adequate for any species (Leakey et al., 1990).

In relation to the sprout length, shown in Table 2, the genotypes with chip budding presented an increased growth and number of leaves. The clone ca294 reached $35.46 \mathrm{~cm}$ long and 30.87 leaves, showing a vigorous vegetative growth in all variables. The splice grafting technique presented the lowest results with an overall mean length of $4.38 \mathrm{~cm}$ (Figure 6).

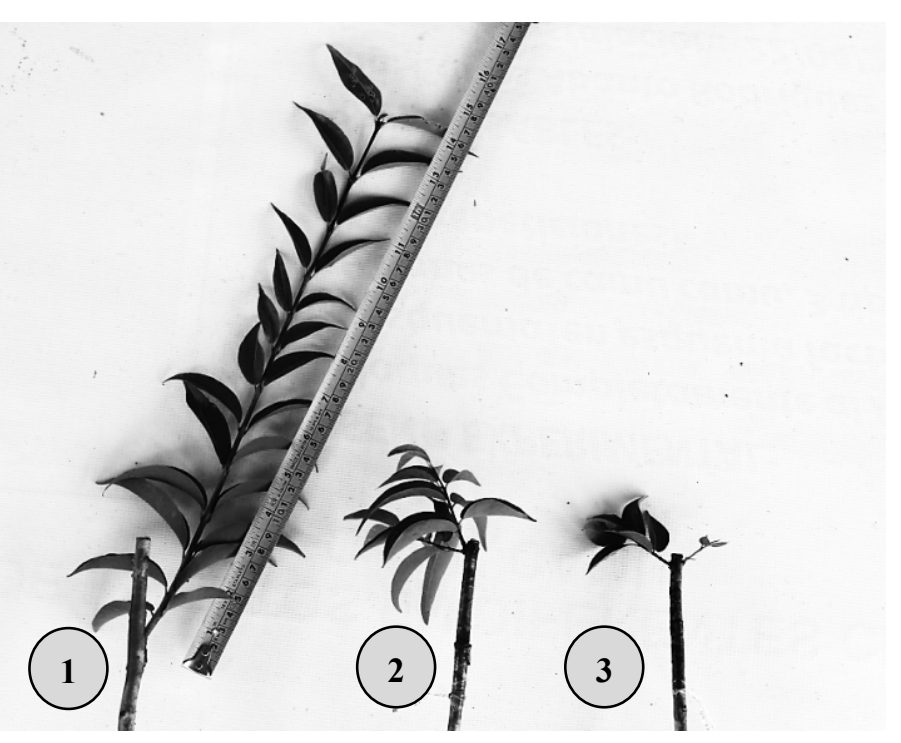

Figure 7. Sprout length and number of leaves depending on the technique of graft: 1) Chip budding, 2) Cleft grafting and 3) Splice graft/Yarinacocha-Ucayali, Peru 


\section{Discussion}

The cleft and splice grafting techniques took less time to sprout, because the portion of plant tissue used as graft has increased sprout length $(5 \mathrm{~cm})$, thereby retaining as much nutrient reserves and requiring less time for sprouting. Furthermore the chip budding has less nutritional reserves, because the region used only comprises a small, thin piece of plant tissue, causing more difficulty of sprouting and survival in a short time, therefore it needs a longer time of development (Simões \& Carvalho, 2006).

For survival rate similar results (65\% success) were obtained by Ferreira and Gentile (1997) working with chip budding on camu camu plants. Enciso (1993) found that chip budding was the best technique achieving greater success in camu camu. Similarly, Suguino (2002) working with camu camu grafting with different rootstocks of Myrtaceae, showed that the best method was the chip budding technique with $78.96 \%$ of survival, while the whip and tongue graft had an average of $25.83 \%$, resulting in lower statistical percentage compared to the other treatments. Moreira Filho (2009) working with camu camu shrub (Myrciaria dubia) grafting on camu camu tree (Myrciaria floribunda), verified that the best survival rates were achieved with the same species, but found different behaviors in terms of success of grafting technique, with chip budding $(89.3 \%$, cleft graft $51.6 \%$ and $31.5 \%$ in splice grafting, and very similar to the results found in this work.

The observed differences between genotypes and graft success may be related to various aspects. The genetic factor is important, since different genotypes may respond differently regarding the ability of vegetative propagation, either by grafting or by another technique, such as the cleft grafting (Franzon et al., 2010). In that sense Salazar et al. (2012) working with different genotypes and different grafting techniques found that MD-017 and MD-015 genotypes with cleft grafting achieved the highest percentage of sprouting with 90.0 and $87.5 \%$; respectively, while the chip budding technique only obtained $55 \%$ of survival rate. A very different result was found in this study, probably because it worked with different genetic material. According to Rodríguez et al. (1995) the formation of plant organs (sprouts, leaves, flowers and fruits) is genetically controlled.

Similarly Rojas et al. (2004) express that genotype affects the concentration of the hormones responsible for growth, which is important when the vegetative propagation of any plant species is performed. Moreover this indicates that proper hormonal regulation promotes sprouts formation on scions. On the other hand Bezerra et al. (2002) mentioned that potentially lower rates observed in some clones are caused by incompatibility between the tissues, as it is a result physiological and anatomical affinity. It can be related to the grafting zone, which can be selective and can hinder the transport of sap between the parts or related to cambial tissue formation in a rootstock/scion connection, which can have different cell sizes, shape and consistency committing th scion afterwards.

Moreover, Simão (1998) emphasizes that for successful union between two plants of the same variety or species, a perfect union of the cambial layers and the parts should have and free from contamination. The time must be appropriate for each species or technique of graft, executed in suitable climatic and soil conditions and be proficient in the handling of tools and appropriate cultural practices during and after welding.

Similar results related to sprout length and number of leaves were obtained by Leal (2001) to verify that the chip budding technique had the highest sprout growth in Neem (Azadiracha indica A. Juss). According to the results, the sprout length and the number of leaves are closely related because the new leaves synthesize gibberellins, which activate the production of cytokinins that are responsible for stimulating the meristematic activity and mobilization of nutrients, creating a good photosynthetic balance is favorable for sprout growth (Vallejo, 2001).

According to the results, chip budding is best suited for camu camu, because in addition to presenting the best survival rates and higher growth, this was the most practical to implement. The speed of execution provided less tissues exposure to the environment, reducing the oxidation reaction of the phenolic compounds. These compounds, when in contact with air, results in oxidation of tissues hindering callus formation and the healing process (Fachinello et al., 2005).

\section{Conclusions}

In these work conditions it is possible to conclude that genotypic variability and grafting technique significantly influence the camu camu vegetative popagation.

The high survival rate and more vigorous vegetative growth obtained with the chip budding technique allow us to recommend the use of this technique for vegetative propagation of camu camu genotypes studied.

\section{Acknowledgements}

We thank the Research Institute of the Peruvian Amazon-IIAP, for the financial support to carry out the 
experiment and technician Marden Paifa Paifa for their dedication in conducting the field work.

\section{References}

Abanto, C. R., Chagas, E. A., Choy, S. J., Andrade dos Santos, V., Lozano, R. M. B., \& Ríos, G. S. (2014). Capacidad de enraizamiento de plantas matrices promisorias de Myrciaria dubia (Kunth) Mc Vaugh en cámaras de subirrigación. Rev. Ceres, Viçosa, 61(1), 134-140. http://dx.doi.org/10.1590/S0034-737X2014000100018

Almeida, L. F. P., Yuyama, K., Chagas, E. A., Lozano, R. M. B., Albuquerque, T. C. S., Abanto, C. R., \& Queiroz, F. B. (2014). Early Evaluation of Camu-Camu Subsamples in Transition Savanna/Forest Area. Journal of Agricultural Science, 6(11), 178-186. http://dx.doi.org/10.5539/jas.v6n11p178

Bezerra, J. E. F., Lederman, I. E., Freitas, E. V., \& Silva Junior, Da J. F. (2002). Propagação de genótipos de pitangueira (Eugenia uniflora L.) pelo método de exertía de garfagem no topo em fenda cheia. Revista $\begin{array}{llll}\text { Brasileira de } \quad \text { Fruticultura, } & \text { Jaboticabal-SP, } & \text { 24(1), }\end{array}$ http://dx.doi.org/10.1590/S0100-29452002000100035

Chagas, A. E., Bacelar-Lima, C. G., Carvalho, A. S., Ribeiro, G. M. I., Sakazaki, T. R., \& Neves, C. L. (2012). Propagação do camu-camu (Myrciaria dubia (H.B.K.) Mc Vaugh). Revista Agro@mbiente, 6, 67-73.

Enciso Narazas, R. M., \&Villachica, H. (1993). Producción y manejo de plantas injertadas de camu-camu (Myrciaria dubia) en vivero. Informe técnico (No. 25, p. 20). Instituto Nacional de Investigación Agrária.

Fachinello, J. C., Hoffmann, A., \& Natchigal, J. C. (2005). Propagação de plantas frutíferas (p. 221). Brasilia, Embrapa informações tecnológicas.

Ferreira, D. F. (2010). SISVAR - Sistema de análise de variância (Versão 5.3). Lavras-MG: UFLA.

Ferreira, S. A. do N., \& Gentil, D. F de O. (1997). Propagação assexuada do camu-camu (Myrciaria dubia) através de exertias do tipo garfagem. Revista Acta Amazônica, 27(3),163-168.

Franzon, C. R., Gonçalves, Da S. R., Antunes, C. L. E., \& Raseira, B. M. C. (2010). Propagação vegetativa de genótipos de pitangueira (Eugenia uniflora L.) do sul do Brasil por enxertia de garfagem. Revista Brasieira de Fruticultura, Jaboticabal-SP, 32(1), 262-267. http://dx.doi.org/10.1590/S0100-29452010005000003

Giraldo, A. L., Ríos, F. H., \& Polanco, F. M. (2009). Efecto de dos enraizadores en tres especies forestales promisorias para la recuperación de suelos. Revista de investigación Agraria y Ambiental, 0(1), 41-47.

Hartmann, H., Kester, D., Davie, F., \&Genever, R. (2002). Plant Propagation: Principles and practices (7th ed., p. 880). New Jersey, Pretince Hall.

IIAP. (2014). Estación meteorológica del Instituto de Investigaciones de la Amazonía Peruana. Yarinacocha, Pucallpa, Ucayali.

Leakey, R., Mesen, F., Tchoundjeu, Z., Longman, A., \& Newton, A. (1990). Low technology types for vegetative propagation of tropical trees. Common Wealth Forestry Review, 66, 61-75.

Leal, O. E. (2001). Memoria técnica $\mathrm{N}^{\circ} 1$. XXX aniversario del campo experimental todos Santos. Memoria-Potencialidades y manejo del Neen (1st ed., p.102). Instituto Nacional de Investigaciones forestales, Agrícolas y pecuárias (INIFAP). La Paz, B.C.S. México.

Moreira Filho, M., \& Ferreira, S. A. N. (2009). Clonagem do camu camu arbustivo em porta-exertos de camu-camu arbustivo e arbóreo. Revista Brasileira de Fruticultura, Jaboticabal-SP, 31(4), 1202-1205. http://dx.doi.org/10.1590/S0100-29452009000400039

Pinedo, P. M., Delgado, V. C., Farroñay, P. R., Imán, C. S., Villacrés, V. J., Faching, M. L., ... Veja, V. R. (2010). Cати-Сати (Myrciaria dubia-Myrtaceae): Aportes para su Aprovechamiento Sostenible en la Amazonia Peruana (p. 130). Iquitos, FINCyT.

Rodríguez, F., Escobedo, R., Bendayán, L., Marquina, L., \& Torres, M. (1995). Estudio de suelos de la zona de San Miguel. Documento Técnico $N^{o} 04$ (p. 24). Instituto de Investigaciones de la Amazonía Peruana. Iquitos-Perú.

Rojas, G. S. (2004). Propagación asexual de plantas. Conceptos básicos y Experiencias con Especies Amazónicas (p. 55). Corporación Colombiana de Investigación Agropecuaria. Editorial Produmedios. Caquetá, Colombia.

Rosati, A, G., \& Arana, C. C. (2003). Cartilla para la propagación del camu camu (Myrciaria dubia H.B.K. Mc Vaugh) mediante injerto (1st ed., p. 17). Fondo de las Américas y Centro de Investigación en Recursos 
Géticos y Biotecnología Vegetal-Cirgebv-Universidad Nacional Agraria La Molina. Lima, Mayo.

Salazar, R. R. A., Correa, I. A. S., \& Ríos, S. A. J. (2012). Influencia del genotipo y tipo de injerto en la brotación de Myrciaria dubia (H.B.K) Mc Vaugh "camu camu". Revista Ciencia Agrónomica, 2(2), 146-150.

Simão, S. (1998). Tratado de fruticultura (pp. 67-121). Piracicaba: Fealq, cap. 2.

Simões, F., \& Carvalho, de N. I. R. (2006). Avaliação de diferentes métodos de sobre-exertia na substituição da cultivar de macieira (Malus domestica Borkh) Gala por princesa. Acta Sci. Agron. Maringá, 28(4), 493-498. http://dx.doi.org/10.4025/actasciagron.v28i4.781

Suguino, E. (2002). Propagação vegetativa do camu-camu (Myrciaria dubia (H.B.K.) Mc Vaugh) por meio da garfagem em diferentes porta-exertos da familia Myrtaceae (p. 76). Dissertação de mestrado. Piracicaba. SP.

Vallejo, U. V. (2001). Morfología y desarrollo vegetativo de los frutales. Monografías de fruticultura №5 (1st ed., p. 212). Escuela Técnica Superior de Ingeniería Agraria. Universidad de Lleida.

Vásquez, A. (2000). El camu camu. Cultivo, manejo e investigaciones (p. 218). Iquitos, Editora Gráfica.

\section{Copyrights}

Copyright for this article is retained by the author(s), with first publication rights granted to the journal.

This is an open-access article distributed under the terms and conditions of the Creative Commons Attribution license (http://creativecommons.org/licenses/by/3.0/). 